\title{
sciendo
}

\section{EFFECT OF RYE GRAIN DERIVED FROM DIFFERENT CULTIVARS OR MAIZE GRAIN USE IN THE DIET ON RUMINAL FERMENTATION PARAMETERS AND NUTRIENT DIGESTIBILITY IN SHEEP*}

Patrycja Rajtar ${ }^{1}$, Paweł Górka ${ }^{1}$, Bogdan Śliwiński², Jarosław Wieczorek³ ${ }^{3}$, Danuta Boros ${ }^{4}$, Piotr Micek ${ }^{1 \bullet}$

\author{
${ }^{1}$ Department of Animal Nutrition and Biotechnology, and Fisheries, \\ University of Agriculture in Krakow, Kraków, Poland \\ ${ }^{2}$ Department of Animal Nutrition and Feed Science, National Research Institute of Animal Production, \\ 32-083 Balice n. Kraków, Poland \\ ${ }^{3}$ Institute of Veterinary Sciences, University Centre of Veterinary Medicine UJ-UR, Kraków, Poland \\ ${ }^{4}$ Plant Breeding and Acclimatization Institute - National Research Institute in Radzików, \\ 05-870 Błonie, Poland \\ •Corresponding author: piotr.micek@urk.edu.pl
}

\begin{abstract}
Six wether sheep with ruminal and duodenal cannulas were used in a replicated $3 \times 3$ Latin square to determine the effect of rye grain (from an open-pollinated or a hybrid cultivar) and maize grain from hybrid cultivar inclusion in the diet on ruminal fermentation parameters and nutrient digestion in different gastrointestinal tract compartments. The experimental diets consisted of meadow hay $(800 \mathrm{~g} / \mathrm{day})$ and a concentrate mixture $(300 \mathrm{~g} / \mathrm{day})$ that contained rye grain from an openpollinated cultivar (OPRG), rye grain from a hybrid cultivar (HRG), or maize grain from a hybrid cultivar (MG) as a main energy source. Each experimental period lasted 17 days and consisted of 10 days for diet adaptation and 7 days for data and sample collection. Ruminal fermentation $(\mathrm{pH}$, short-chain fatty acids, and ammonia concentration) and nutrient digestion up to the duodenum (in reticulorumen, omasum, and abomasum), in the intestine, as well as in the total digestive tract was investigated. Mean ruminal $\mathrm{pH}$ was higher for MG compared to HRG and OPRG $(\mathrm{P}<0.01)$ but did not differ between HRG and OPRG (6.45, 6.35, and 6.29 for MG, HRG, and OPRG, respectively). Treatment did not affect short-chain fatty acid concentration in the rumen, except for the molar proportions of valeric acid and of isovaleric acid of the total short-chain fatty acids, which was or tended to be higher $(\mathbf{P} \leq \mathbf{0 . 0 6})$ for MG compared to HRG and OPRG. Less starch was digested in the gastrointestinal tract up to the duodenum and more in the intestine for MG compared to HRG and OPRG $(P=0.01)$; however, total tract nutrient digestibility did not differ between treatments. In conclusion, usage of rye grain in sheep diets resulted in a lower ruminal pH compared to maize grain usage. No differences for ruminal fermentation, nutrient digestion up to the duodenum, in the intestine, as well as in the total digestive tract between rye grain from open-pollinated and hybrid cultivar usage in sheep diets were found.
\end{abstract}

Key words: cereal grain, cultivar, digestion, ruminants

*The project was supported by funds from the National Centre for Research and Development (NCRD), grant ENERGYFEED, project No. BIOSTRATEG2/297910/12/NCBR/2016. 
Rye grain (Secale cereale L.) is not commonly used in diets for ruminants (Heuzé et al., 2015), mostly because of concerns about ergot alkaloid contamination (Warren et al., 1963) but also because of the potentially lower palatability of rye grain compared to other cereal grains (Sharma et al., 1981). However, cultivars of hybrid rye which offer several agronomic benefits over older, open-pollinated cultivars have been developed relatively recently. Those benefits include greater yield as well as greater drought, pest, and frost resistance (Geiger and Miedaner, 2009; Jürgens et al., 2012; Katina et al., 2014). Those rye hybrids have also reduced susceptibility to ergot contamination and reduced concentrations of antinutritional factors commonly present in rye grain, including trypsin inhibitors and alkylresorcinols (Makarska et al., 2007; Miedaner and Geiger, 2015). Thus, the use of rye grain from hybrid cultivars in ruminant nutrition may yield satisfying results. In support of this, a few studies conducted to date have shown that feeding hybrid rye grain to early-lactating dairy cows had no negative effect on dry matter intake and milk yield (Pieszka et al., 2015). Furthermore, hybrid rye grain usage yielded satisfying results also in diets for monogastrics. Specifically, the proportion of hybrid rye grain may be substantially increased in diets for pigs and poultry (e.g., up to $25 \%$ in compound feed) without the risk of reduced animal performance (Schwarz et al., 2015; Smit et al., 2019; Arczewska-Włosek et al., 2019; Bederska-Łojewska et al., 2019; Węsierska et al., 2019).

The starch of rye grain is rapidly fermented in the rumen, which may limit its use in the diets for ruminants (Benninghoff et al., 2015; Krieg et al., 2017; Rajtar et al., 2020). The same applies to other cereal grains, such as wheat, barley, or triticale, contributing to the high popularity of maize as a main source of energy in diets for ruminants (McGrath et al., 2018; Loy and Lundy, 2019). However, Silveira et al. (2007), Zhao et al. (2016), and Krieg et al. (2017) reported a huge variation in the ruminal degradation of rye grain and barley grain derived from different cultivars. Moreover, Silveira et al. (2007) found differences in ruminal $\mathrm{pH}$, ruminal propionate and acetate concentrations, and total tract digestibility in dairy cows fed diets with two different barley cultivars. Variations in ruminal degradation have also been shown for different wheat genotypes (Seifried et al., 2016). Furthermore, in pigs, differences in intestinal digestibility of amino acids were shown when rye grain derived from various genotypes was compared (Strang et al., 2016). Thus, due to possible differences in the concentrations of some nutrients (e.g., carbohydrates, amino acids) and antinutritional factors between open-pollinated and hybrid rye grain (Strang et al., 2016; Makarska et al., 2007; Miedaner and Geiger, 2015), differences in their digestibility can also be expected in ruminants. However, in vivo studies documenting the potential differences in ruminal fermentation as well as post-ruminal digestibility of different genotypes of rye grain are lacking.

The hypothesis of this study was that ruminal fermentation and nutrient digestibility of rye grain from hybrid and open-pollinated cultivars differ. To hasten this hypothesis verification, animals were also fed a diet with maize grain, the most popular source of energy in diets for ruminants. The aim of this study was to determine the impact of hybrid rye grain, open-pollinated rye grain, and maize grain usage in the diets for ruminants on ruminal fermentation parameters $(\mathrm{pH}$, short-chain fatty acids, 
and ammonia concentration in rumen fluid) and nutrient digestibility. In this study, sheep were used as model animals.

\section{Material and methods}

\section{Animals, experimental design, and treatments}

The study was conducted between December 2015 and January 2016. Prior to the study, the experimental procedures were reviewed and approved by the Local Institutional Animal Care and Use Committee (Kraków, Poland; protocol No. 224/2015). Six Polish Longwool Sheep wethers $(40.7 \pm 4.67 \mathrm{~kg}$ body weight, at 18 to 20 months of age) fitted with permanent ruminal cannula (soft plastic, 75-mm opening diameter; Bar Diamond Inc., Parma, ID) and self-made duodenal T-type cannula (highdensity polyethylene, oval barrel with an opening of $158 \mathrm{~mm}^{2}$ ) were used in a $3 \times 3$ replicated Latin square design. Each experimental period lasted 17 days and included 10 days of adaptation and 7 days for data and sample collection. The wethers were kept in individual pens $(160 \times 90 \mathrm{~cm})$ bedded with small amounts of wood shavings that were added daily. Prior to the study, the wethers were stratified by body weight and then allocated to the replicate (i.e., to obtain one replicate with higher and one replicate with lower initial body weight of animals).

The animals were fed a diet consisting of $800 \mathrm{~g}$ of chopped $(\approx 5 \mathrm{~cm})$ meadow hay/day and $300 \mathrm{~g}$ of a mixture of concentrates/day with rye grain from a hybrid cultivar (HRG; cultivar Bono; KWS Lochow, Prusy, Poland), rye grain from an open-pollinated cultivar (OPRG; cultivar Dańkowskie Opal; KWS Lochow, Prusy, Poland), or maize grain from a hybrid cultivar (MG; cultivar Podium; KWS Lochow, Prusy, Poland) used as a main source of energy, resulting in three experimental treatments (Table 1). Thus, feed intake was restricted in the current study. Cereal grains were harvested in 2015, and thus, grains for the study originated from the same year. Besides rye (open-pollinated or hybrid) or maize, the mixture of concentrates contained soybean meal, salt, and vitamin-mineral supplement (Table 2). Cereal grains and soybean meal were ground to pass through a 4-mm screen, and subsequently, vitamin-mineral supplement and salt were added and mixed to obtain a homogeneous mixture. The diets were formulated to be isonitrogenous, and the treatments HRG and OPRG were similar for starch and non-fibrous carbohydrates (NFC). The diets met the nutrient requirements of sheep (INRA, 2007).

The diet was divided into two equal meals and fed at 06:00 and 18:00. Prior to feeding, hay and the mixture of concentrates were individually weighed for each animal into the feeder and mixed carefully. The animals had ad libitum access to water.

\section{Duodenal flow, digestibility, and rumen fermentation}

Sampling of digesta and feces and calculation of nutrient digestibility followed the procedures described previously by Górka et al. (2017), with minor modification. In brief, digesta flow to the duodenum was determined using the single marker method and $\mathrm{YbCl}_{3}$ (modified from Siddons et al., 1985) as the digesta marker. The 
marker solutions were prepared (separately for each period of the study) using double-distilled water and infused directly into the rumen from day 11 to day 17 of each experimental period, using a peristaltic pump (Minipuls Evolution; Gilson) at a constant rate of $200 \mathrm{~mL} /$ day; $155 \mathrm{mg}$ of $\mathrm{Yb}$ were infused into the rumen daily (van Ryssen and Mavimbela, 1999). Samples of the marker solutions (20 mL) were collected and stored frozen $\left(-20^{\circ} \mathrm{C}\right)$ for further marker concentration analysis.

Table 1. Ingredients and chemical composition of the experimental diets

\begin{tabular}{|c|c|c|c|}
\hline \multirow{2}{*}{ Item } & \multicolumn{3}{|c|}{ Treatment $^{1}$} \\
\hline & MG & HRG & OPRG \\
\hline \multicolumn{4}{|l|}{ Concentrate mixture $(\mathrm{g} / \mathrm{kg})$} \\
\hline maize grain & 831 & & \\
\hline hybrid rye grain & & 851 & \\
\hline open-pollinated rye grain & & & 805 \\
\hline soybean meal & 137 & 117 & 163 \\
\hline mineral-vitamin suplement ${ }^{2}$ & 30 & 30 & 30 \\
\hline salt & 2 & 2 & 2 \\
\hline \multicolumn{4}{|l|}{ Diet (g/day) } \\
\hline maize grain & 249.3 & & \\
\hline hybrid rye grain & & 255.3 & \\
\hline open-pollinated rye grain & & & 241.5 \\
\hline soybean meal & 41.1 & 35.1 & 48.9 \\
\hline mineral-vitamin suplement ${ }^{2}$ & 9.0 & 9.0 & 9.0 \\
\hline salt & 0.6 & 0.6 & 0.6 \\
\hline meadow hay ${ }^{3}$ & 800 & 800 & 800 \\
\hline \multicolumn{4}{|l|}{ Chemical composition of diets } \\
\hline Dry Matter (DM) (\%) & $82.07 \pm 0.05$ & $81.87 \pm 0.10$ & $81.86 \pm 0.09$ \\
\hline ash $(\% \mathrm{DM})$ & $7.30 \pm 0.04$ & $7.44 \pm 0.04$ & $7.40 \pm 0.04$ \\
\hline crude protein $(\% \mathrm{DM})$ & $9.60 \pm 0.08$ & $9.38 \pm 0.10$ & $9.46 \pm 0.06$ \\
\hline crude fat $(\% \mathrm{DM})$ & $2.19 \pm 0.03$ & $1.50 \pm 0.01$ & $1.46 \pm 0.00$ \\
\hline $\mathrm{NDF}^{4}(\% \mathrm{DM})$ & $47.31 \pm 0.06$ & $49.58 \pm 0.06$ & $49.44 \pm 0.05$ \\
\hline $\mathrm{ADF}^{5}(\% \mathrm{DM})$ & $29.06 \pm 0.01$ & $29.18 \pm 0.01$ & $29.00 \pm 0.01$ \\
\hline $\operatorname{starch}(\% \mathrm{DM})$ & $14.95 \pm 0.46$ & $12.73 \pm 0.25$ & $13.11 \pm 0.19$ \\
\hline $\mathrm{NFC}^{6}(\% \mathrm{DM})$ & $33.60 \pm 0.08$ & $32.10 \pm 0.01$ & $32.24 \pm 0.05$ \\
\hline
\end{tabular}

${ }^{1}$ Treatment: $\mathrm{MG}=$ maize grain as a main source of energy in concentrate mixture, $\mathrm{HRG}=$ hybrid rye grain as a main source of energy in concentrate mixture, $\mathrm{OPRG}=$ open-pollinated rye grain as a main source of energy in concentrate mixture.

${ }^{2}$ Polfamix KO (as fed): $200 \mathrm{~g} \mathrm{Ca}, 60 \mathrm{~g} \mathrm{Na}, 120 \mathrm{~g} \mathrm{P}, 65 \mathrm{~g} \mathrm{Mg}, 300,000 \mathrm{IU}$ vitamin A, 30,000 IU vitamin D, $1,500 \mathrm{mg}$ vitamin E, 3,000 mg Mg, 2,500 mg Zn, $50 \mathrm{mg} \mathrm{I}, 3 \mathrm{mg} \mathrm{Se}, 15 \mathrm{mg}$ Co.

${ }^{3}$ Chemical composition: $87.41 \%$ DM, $8.68 \%$ ash, $7.54 \%$ CP, $1.65 \%$ crude fat, $64.41 \%$ NDF, $40.01 \%$ ADF.

${ }^{4}$ Neutral detergent fiber.

${ }^{5}$ Acid detergent fiber.

${ }^{6}$ Non-fibrous carbohydrates $=100-(\mathrm{NDF}+$ crude protein + crude fat + ash $)$. 
Table 2. Chemical composition and carbohydrate structure of maize grain, hybrid rye grain, and open-pollinated rye grain $(\mathrm{g} / \mathrm{kg} \mathrm{DM})$

\begin{tabular}{lcccc}
\hline \multicolumn{1}{c}{ Item } & Maize grain & Hybrid rye grain & Open-pollinated rye grain \\
\hline Crude protein & 117.5 & 127.5 & 106.3 \\
Crude fat & 42.1 & 13.7 & 24.3 \\
Ash & 14.4 & 17.1 & 16.5 \\
Starch & 780.8 & 652.5 & 704.2 \\
NDF $^{1}$ & 85.0 & 165.7 & 131.1 \\
$\mathrm{ADF}^{2}$ & 30.7 & 45.0 & 42.2 \\
$\mathrm{ADL}^{3}$ & 18.4 & 10.6 & 12.3 \\
NFC $^{4}$ & 741.0 & 676.0 & 721.8 \\
T-NSP $^{5}$ & 48.7 & 131.8 & 130.6 \\
WIS-NSP $^{6}$ & 19.0 & 51.1 & 48.8 \\
WS-NSP $^{7}$ & 1.70 & 23.5 & 26.1 \\
TDF & & 61.8 & 161.8 & 158.2 \\
Arabinose & 6.50 & 19.3 & 19.0 \\
Xylose & 7.30 & 30.4 & 30.9 \\
Mannose & 3.00 & 4.40 & 4.40 \\
Galactose & 1.70 & 2.30 & 2.20 \\
Glucose & 13.7 & 31.0 & 30.2 \\
\hline
\end{tabular}

${ }^{1}$ Neutral detergent fiber.

${ }^{2}$ Acid detergent fiber.

${ }^{3}$ Acid detergent lignin.

${ }^{4} \mathrm{Non}-$ fibrous carbohydrates $=1000-(\mathrm{NDF}+$ crude protein + crude fat + ash $)$.

${ }^{5}$ Total content of non-starch polysaccharides.

${ }^{6}$ Water-insoluble non-starch polysaccharides.

${ }^{7}$ Water-soluble non-starch polysaccharides.

${ }^{8}$ Total dietary fiber.

Apparent total tract digestibility was determined by total fecal collection from day 11 to day 14 of each experimental period. The feces were collected into canvas collection bags strapped to the hindquarters of the wethers, as proposed by Pfister (1985) with minor modifications. The bags were emptied twice a day (07:30 and $17: 30 \mathrm{~h}$ ), and $15 \%$ of daily fecal output was collected, pooled by animals and period, and stored at $-20^{\circ} \mathrm{C}$ for further analysis. From day 15 to day 17 of each period, 12 samples of duodenal digesta were collected at 06:00, 12:00, 18:00, and 00:00 $\mathrm{h}$ on day $15 ; 04: 00,10: 00,16: 00$, and 22:00 h on day 16; and 02:00, 08:00, 14:00, and 20:00 h on day 17 to reflect 24-h feeding cycle (Chibisa et al., 2012; Górka et al., 2017). At each sampling time, $150-200 \mathrm{~mL}$ of whole duodenal digesta were collected and kept at $-20^{\circ} \mathrm{C}$ for further processing.

Immediately after duodenal digesta sampling, a probe (rubber tube covered with thin metal net) was inserted into the rumen via a rumen cannula, and $100 \mathrm{~mL}$ of rumen fluid were aspirated from the ventral sack of the rumen. Subsequently, $5 \mathrm{~mL}$ of rumen fluid were mixed with $1 \mathrm{~mL}$ of metaphosphoric acid $(25 \% \mathrm{wt} / \mathrm{vol})$ and $4 \mathrm{~mL}$ of rumen fluid with $0.2 \mathrm{~mL}$ of saturated $\mathrm{HgCl}_{2}$ solution. The rumen fluid samples were pooled by wethers and period to obtain one sample, which was used for 
analysis of short-chain fatty acids (SCFA) and $\mathrm{N}-\mathrm{NH}_{3}$ concentration. Furthermore, from day 11 to day 13 of each experimental period, the rumen $\mathrm{pH}$ in the ventral sack of the rumen was measured every 1 min using a small ruminant $\mathrm{pH}$ measurement system (Dascor, Escodido, CA), as described and validated by Penner et al. (2009).

Feed samples were collected weekly and pooled by period before analysis. If they occurred, refusals were also collected and stored frozen $\left(-20^{\circ} \mathrm{C}\right)$ until analysis. Furthermore, samples of hybrid rye grain, open-pollinated rye grain, and maize grain (whole grains) were collected at the stage of concentrate mixture preparation and stored at room temperature for further analysis.

\section{Sample analysis}

Samples of the whole duodenal digesta were freeze-dried. Fecal samples (after thawing), feeds (mixture of concentrates, hay, and samples of cereal grains), and refusals (after thawing) were dried in a forced air oven at $55^{\circ} \mathrm{C}$ for $72 \mathrm{~h}$. Subsequently, the samples were ground to pass through a 1-mm screen and analyzed for dry matter (DM), ash, crude protein (CP), neutral detergent fiber (NDF), and acid detergent fiber (ADF), as described previously by Górka et al. (2017). Starch content was analyzed as described by Faisant et al. (1995). Acid detergent lignin (ADL) was analyzed as described by Robertson and Van Soest (1981). Based on the chemical composition of the mixture of concentrates and hay, the diet composition was mathematically estimated, including NSC concentration.

Concentrations of total non-starch polysaccharides (T-NSP), water-soluble polysaccharides (WS-NSP), and water-insoluble polysaccharides (WIS-NSP) in cereal grains were determined by gas chromatography (Englyst and Cummings, 1984). In this procedure, the non-starch polysaccharides of each fraction represent the sum of individual monomers, including arabinose, xylose, mannose, galactose, and glucose. Briefly, after enzymatic hydrolysis of starch, the samples were centrifuged and split into soluble (ethanol precipitates from supernatant) and insoluble (remaining pellet) fractions. Each fraction was hydrolyzed with $1 \mathrm{M}$ sulfuric acid $\left(100^{\circ} \mathrm{C}, 2 \mathrm{~h}\right)$ to obtain monosaccharides and converted to volatile alditol acetates. The alditol acetates were separated on a capillary quartz column Rtx-225 $(0.53 \mathrm{~mm} \times 30 \mathrm{~m})$ using a Clarus 500 gas chromatograph (Perkin Elmer) equipped with an autosampler, splitter injection port, and flame ionization detector. The carrier gas was helium. Separation was performed at $225^{\circ} \mathrm{C}$ and injection and detection at $275^{\circ} \mathrm{C}$. Total dietary fiber (TDF; method no. 32-25; AACC, 2011) was calculated as the sum of T-NSP and lignin content (Theander et al., 1995).

The concentration of $\mathrm{Yb}$ in the duodenal digesta, fecal samples, and infusing media was analyzed by ICP-OES using the Perkin Elmer Optima 7300 DV instrument after sample ashing in the mixture of concentrated $\mathrm{HNO}_{3}$ and $\mathrm{HClO}_{4}(1: 1.5 ; \mathrm{v} / \mathrm{v})$ in the presence of $\mathrm{KCl}(2 \mathrm{~g} / \mathrm{L})$ (PN-EN 1233:2000P).

Ruminal SCFA were determined in a gas chromatograph (3400 CX; Varian Star, Palo Alto, CA) equipped with a flame ionization detector (FID), as described by Erwin et al. (1961), using a DB-FFAP column $(30 \mathrm{~m} \times 0.5 \mathrm{~mm}$; J\&W Scientific, Folsom, CA) and argon as a carrier. The flow rate was set to $4 \mathrm{~mL} / \mathrm{min}$, and the 
temperatures for the column, injector, and detector were set to $90-205^{\circ} \mathrm{C}, 200^{\circ} \mathrm{C}$, and $240^{\circ} \mathrm{C}$, respectively. Ammonia-N was determined as described by Conway (1962).

\section{Calculations and statistical analysis}

In this paper, the disappearance of nutrients in compartments of the gastrointestinal tract posterior to the duodenum will be also referred to as "digestion in the whole stomach" (reticulorumen, omasum, and abomasum).

Feed intake, nutrient content in feeds, and refusals were used to calculate nutrient intake. Marker concentration in consumed DM (calculated based on DM intake and marker infusion into the rumen) and DM of duodenal digesta was used to calculate duodenal flows. Subsequently, nutrient intake, nutrient flow to the duodenum, and nutrients excreted in the feces were used to calculate apparent nutrient digestibility up to the duodenum (in the whole stomach), the intestine, and the entire digestive tract (Górka et al., 2017). The daily ruminal pH measurements (day 11 to day 13 of each period) were summarized as minimum, mean, and maximum $\mathrm{pH}$, and the standard deviation of daily ruminal $\mathrm{pH}$ was also calculated (Penner et al., 2006). For daily ruminal $\mathrm{pH}$ pattern analysis, the means for each hour of the day over 3 days of measurement were used.

Data were analyzed as a replicated Latin square design using the MIXED procedure of SAS (ver. 9.2; SAS Inst. Inc., Cary, NC). Before analysis, normal distribution of the data was verified using PROC UNIVARIATE in SAS, and no data transformation was necessary. The model included the fixed effect of treatment and the random effects of period, replicate, and animal within replicate. For measurements repeated in time (daily ruminal $\mathrm{pH}$ and daily ruminal $\mathrm{pH}$ pattern), a REPEATED statement was included in the statistical model, with the compound symmetry covariance structure chosen on the basis of the lowest Akaike information criteria. Preplanned contrasts were used for scientific hypothesis verification, i.e., to compare the impacts of hybrid and open-pollinated rye grain in the diet on the investigated variables (OPRG vs. HRG) as well as to compare the effects of maize grain feeding with the effects of rye grain feeding (MG vs. OPRG and $\mathrm{HRG}$ ).

One animal was excluded from statistical analysis due to permanent rumen cannula loss in the last period of the study, resulting in available data only for two periods for this animal. Thus, the presented results correspond to five animals. However, prior to removal of the aforementioned animal from the data set, statistical analysis with and without data collected for this animal was run, and the results, in general, did not change, also when the WEIGHT option in SAS was included in the model to account for the different numbers of observations between treatments.

The results are presented as least square means and their corresponding standard errors. Significance was declared at $\mathrm{P} \leq 0.05$, and tendencies were discussed when $\mathrm{P} \leq 0.10$.

\section{Results}

Compared with maize grain, rye grain (open-pollinated and hybrid) contained more CP, NDF, and ADL, but less ADF, starch, and crude fat (Table 2). Hybrid rye 
grain had a slightly lower starch content compared to open-pollinated rye grain. The T-NSP in rye was 2.7 times higher than that in maize, mainly due to a greater proportion of WS-NSP, with 14 to 15 times higher values in rye grain (depending on the cultivar) than in maize grain. Open-pollinated and hybrid rye grain contained 2.6 times more TDF, 2.9 times more arabinose, 2.3 time more glucose, and 4.2 times more xylose compared to maize grain. No substantial differences for T-NSP, WISNSP, TDF, arabinose, xylose, mannose, galactose, and glucose concentrations between hybrid rye grain and open-pollinated rye grain were observed.

Table 3. Effects of maize grain, hybrid rye grain, and open-pollinated rye grain use in the diet on dry matter intake and ruminal fermentation in sheep

\begin{tabular}{|c|c|c|c|c|c|c|c|}
\hline & \multicolumn{3}{|c|}{ Treatment $^{1}$} & \multirow[b]{2}{*}{$\mathrm{SEM}^{2}$} & \multirow[b]{2}{*}{ P-value } & \multicolumn{2}{|c|}{ Contrast } \\
\hline & MG & HRG & OPRG & & & $\begin{array}{c}\text { MG vs. HRG } \\
\text { and OPRG }\end{array}$ & $\begin{array}{c}\text { HRG vs. } \\
\text { OPRG }\end{array}$ \\
\hline Dry matter intake (g/d) & 968 & 964 & 951 & 5.02 & 0.35 & 0.34 & 0.26 \\
\hline Rumen $\mathrm{SCFA}^{3}(\mathrm{mmol} / \mathrm{L})$ & 92.0 & 89.7 & 97.1 & 13.1 & 0.63 & 0.84 & 0.36 \\
\hline Acetic acid (\% SCFA) & 65.2 & 66.8 & 65.6 & 1.75 & 0.35 & 0.33 & 0.29 \\
\hline Propionic acid (\% SCFA) & 21.5 & 21.2 & 21.7 & 1.62 & 0.93 & 0.95 & 0.72 \\
\hline Butyric acid (\% SCFA) & 11.2 & 10.3 & 11.0 & 0.67 & 0.61 & 0.48 & 0.49 \\
\hline Valeric acid (\% SCFA) & 0.92 & 0.62 & 0.65 & 0.08 & 0.02 & $<0.01$ & 0.76 \\
\hline Isobutyric acid (\% SCFA) & 0.45 & 0.38 & 0.36 & 0.04 & 0.26 & 0.11 & 0.77 \\
\hline Isovaleric acid (\% SCFA) & 0.78 & 0.89 & 0.92 & 0.06 & 0.15 & 0.06 & 0.70 \\
\hline $\mathrm{N}-\mathrm{NH}_{3}(\mathrm{mg} / \mathrm{dL})$ & 9.67 & 10.68 & 9.92 & 1.23 & 0.33 & 0.30 & 0.28 \\
\hline \multicolumn{8}{|l|}{ Rumen $\mathrm{pH}$} \\
\hline mean & 6.45 & 6.35 & 6.29 & 0.11 & 0.01 & $<0.01$ & 0.22 \\
\hline minimum & 6.11 & 5.94 & 5.86 & 0.15 & 0.003 & $<0.01$ & 0.27 \\
\hline maximum & 6.81 & 6.84 & 6.80 & 0.08 & 0.67 & 0.78 & 0.39 \\
\hline standard deviation & 0.14 & 0.20 & 0.20 & 0.02 & $<0.01$ & $<0.01$ & 0.75 \\
\hline
\end{tabular}

${ }^{1}$ Treatment: $\mathrm{MG}=$ maize grain as main source of energy in concentrate mixture, $\mathrm{HRG}=$ hybrid rye grain as a main source of energy in concentrate mixture, $\mathrm{OPRG}=$ open-pollinated rye grain as a main source of energy in concentrate mixture.

${ }^{2}$ Standard error of the mean.

${ }^{3} \mathrm{SCFA}=$ short-chain fatty acids.

All diets had similar ash, CP, and ADF contents (Table 1). Differences were noted for NDF, starch, and fat concentrations. The NDF content was slightly lower for MG compared to HRG and OPRG $(47.31,49.58$, and 49.44\% of DM for MG, OPRG, and OPRG, respectively). The starch concentration was greater for MG (on average by $15 \%$ ) compared to HRG and OPRG $(14.95,12.73$, and $13.11 \%$ of DM), whereas the fat concentration was greater for MG compared to HRG and OPRG $(2.19,1.50$, and $1.46 \%$ of DM). The chemical composition of diets, as planned, did not differ between HRG and OPRG, with the exception of a slightly greater (by 0.38 percentage unit) starch concentration for OPRG compared to HRG.

All animals consumed the amount of feed that was offered daily, with the exception of one wether, which left some feed during the sampling period. This occurred 
independently of the treatment that was applied to this animal in subsequent periods of the study. However, DM intake did not differ between treatments (Table 3).

Treatment did not affect the total SCFA concentration in the rumen fluid (Table 3). The MG treatment resulted in a greater molar proportion of valeric acid $(\mathrm{P}<0.01)$ and a tendency to a greater molar proportion of isovaleric acid $(\mathrm{P}=0.06)$ in total SCFA compared to the HRG and OPRG treatments. Furthermore, MG resulted in higher mean and minimum ruminal $\mathrm{pH}$ and lower standard deviation of ruminal $\mathrm{pH}$ compared to OPRG and HRG $(\mathrm{P}<0.01)$. No other differences for ruminal fermentation were observed between MG vs. OPRG and HRG. Also, no differences between OPRG and HRG for ruminal fermentation characteristics were detected.

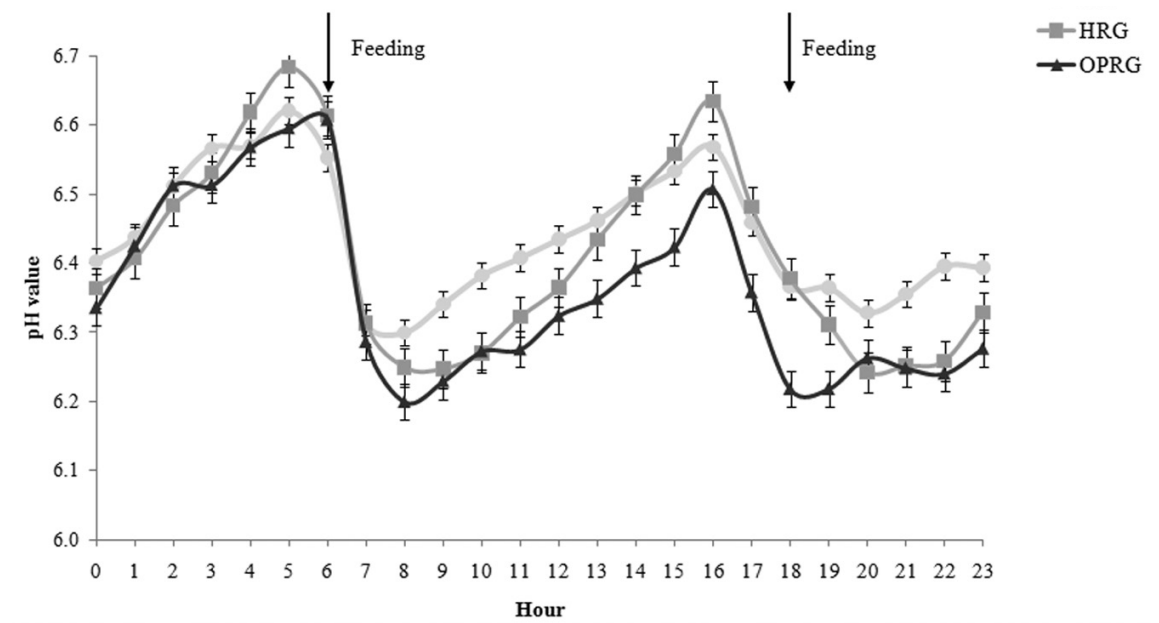

Treatments: $M G=$ maize grain as a main source of energy in concentrate mixture, $H R G=$ hybrid rye grain as a main source of energy in concentrate mixture, $\mathrm{OPRG}=$ open-pollinated rye grain as a main source of energy in concentrate mixture.

Figure 1. Average ruminal $\mathrm{pH}$ fluctuation over 1 day (average of 3 days)

Changes in ruminal $\mathrm{pH}$ during the day showed a typical post-feeding drop and a gradual return to the 'baseline' over the next 12 hours (Figure 1). No interaction between hour of the day and treatment was observed $(\mathrm{P}=0.99)$. When the data were analyzed using the mean value for each hour of the day over 3 days of measurement, mean ruminal $\mathrm{pH}$ was not only higher for MG compared to HRG and OPRG (6.45 vs. 6.35 and 6.28, respectively; $\mathrm{P}<0.01)$ but also for $\mathrm{HRG}$ compared to OPRG (6.35 vs. 6.28 ; $\mathrm{P}<0.01$ ). This was mostly a result of a lower maximum ruminal $\mathrm{pH}$ for the OPRG treatment; however, the difference was relatively minor (0.07 unit).

The treatment led to a higher $\mathrm{CP}$ intake for MG compared to HRG and OPRG $(\mathrm{P}=0.02$; Table 4$)$; however, the difference was only $3 \mathrm{~g} /$ day and reflected minor differences in $\mathrm{CP}$ concentration between the experimental diets. Furthermore, starch intake was greater (by 12 to $13 \% ; \mathrm{P}<0.01$ ) and NDF intake lower (by 3 to $5 \% ; \mathrm{P}=0.04$ ) for $\mathrm{MG}$ compared to $\mathrm{HRG}$ and OPRG. No other differences for nutrient intake were observed between MG vs. HRG and OPRG. No differences for nutrient intake were observed between HRG and OPRG. 
Table 4. Effects of maize grain, hybrid rye grain, and open-pollinated rye grain use in the diet on nutrient intake and apparent nutrient digestibility in sheep

\begin{tabular}{|c|c|c|c|c|c|c|c|}
\hline & \multicolumn{3}{|c|}{ Treatment $^{1}$} & \multirow{2}{*}{$\mathrm{SEM}^{2}$} & \multirow[b]{2}{*}{ P-value } & \multicolumn{2}{|c|}{ Contrast } \\
\hline & MG & HRG & OPRG & & & $\begin{array}{c}\text { MG vs. HRG } \\
\text { and OPRG }\end{array}$ & $\begin{array}{l}\text { HRG vs. } \\
\text { OPRG }\end{array}$ \\
\hline Organic matter intake $(\mathrm{g} / \mathrm{d})$ & 884 & 879 & 867 & 4.55 & 0.31 & 0.27 & 0.26 \\
\hline Flow at duodenum (\% of intake) & 52.2 & 49.6 & 51.5 & 1.11 & 0.37 & 0.34 & 0.30 \\
\hline Digested up to duodenum ${ }^{3,4}(\%)$ & 47.8 & 50.4 & 48.5 & 1.11 & 0.37 & 0.34 & 0.30 \\
\hline \multicolumn{8}{|l|}{ Digested in intestine } \\
\hline$\%$ of intake & 22.0 & 19.0 & 23.4 & 1.91 & 0.46 & 0.82 & 0.25 \\
\hline$\%$ of flow to duodenum & 40.9 & 38.1 & 43.9 & 3.06 & 0.53 & 0.99 & 0.28 \\
\hline Digested in whole tract (\%) & 69.7 & 69.6 & 71.8 & 1.00 & 0.40 & 0.56 & 0.23 \\
\hline Crude protein intake (g/d) & 112 & 109 & 109 & 0.65 & 0.05 & 0.02 & 0.98 \\
\hline Flow at duodenum ( $\%$ of intake) & 100.7 & 108.8 & 112.6 & 3.06 & 0.44 & 0.16 & 0.58 \\
\hline Digested up to duodenum (\%) & -0.7 & -8.8 & -12.6 & 3.06 & 0.31 & 0.15 & 0.58 \\
\hline \multicolumn{8}{|l|}{ Digested in intestine } \\
\hline$\%$ of intake & 67.2 & 75.9 & 82.9 & 3.74 & 0.23 & 0.13 & 0.38 \\
\hline$\%$ of flow to duodenum & 66.5 & 69.7 & 72.8 & 5.66 & 0.14 & 0.10 & 0.25 \\
\hline Digested in whole tract (\%) & 66.4 & 67.3 & 70.4 & 1.14 & 0.21 & 0.24 & 0.15 \\
\hline $\mathrm{NDF}^{5}$ intake $(\mathrm{g} / \mathrm{d})$ & 539 & 567 & 554 & 5.41 & 0.06 & 0.04 & 0.21 \\
\hline Flow at duodenum ( $\%$ of intake) & 41.7 & 39.3 & 41.2 & 1.43 & 0.65 & 0.61 & 0.45 \\
\hline Digested up to duodenum (\%) & 58.5 & 60.7 & 58.8 & 1.43 & 0.65 & 0.61 & 0.45 \\
\hline \multicolumn{8}{|l|}{ Digested in intestine } \\
\hline$\%$ of intake & 7.8 & 6.3 & 10.3 & 2.12 & 0.54 & 0.88 & 0.29 \\
\hline$\%$ of flow to duodenum & 15.6 & 14.4 & 21.1 & 5.10 & 0.68 & 0.78 & 0.42 \\
\hline Digested in whole tract (\%) & 66.3 & 67.0 & 69.3 & 1.00 & 0.32 & 0.32 & 0.24 \\
\hline $\mathrm{ADF}^{6}$ intake $(\mathrm{g} / \mathrm{d})$ & 341 & 342 & 334 & 5.64 & 0.36 & 0.64 & 0.18 \\
\hline Flow at duodenum ( $\%$ of intake) & 48.2 & 41.4 & 44.7 & 1.87 & 0.31 & 0.21 & 0.40 \\
\hline Digested up to duodenum (\%) & 51.8 & 58.6 & 55.3 & 1.87 & 0.31 & 0.21 & 0.40 \\
\hline \multicolumn{8}{|l|}{ Digested in intestine } \\
\hline$\%$ of intake & 12.0 & 6.8 & 9.8 & 2.38 & 0.54 & 0.40 & 0.51 \\
\hline$\%$ of flow to duodenum & 22.5 & 14.5 & 18.0 & 5.01 & 0.67 & 0.46 & 0.68 \\
\hline Digested in whole tract (\%) & 64.6 & 65.5 & 65.1 & 0.81 & 0.83 & 0.60 & 0.78 \\
\hline Starch intake $(g / d)$ & 179 & 156 & 158 & 2.91 & $<0.01$ & $<0.01$ & 0.36 \\
\hline Flow at duodenum ( $\%$ of intake) & 20.5 & 5.0 & 7.0 & 2.72 & 0.02 & 0.01 & 0.71 \\
\hline Digested up to duodenum (\%) & 79.5 & 95.0 & 93.0 & 2.72 & 0.04 & 0.01 & 0.71 \\
\hline \multicolumn{8}{|l|}{ Digested in intestine } \\
\hline$\%$ of intake & 20.2 & 5.0 & 7.0 & 2.67 & 0.04 & 0.01 & 0.70 \\
\hline$\%$ of flow to duodenum & 100.0 & 40.8 & 38.9 & 13.65 & 0.15 & 0.06 & 0.95 \\
\hline Digested in whole tract (\%) & 99.7 & 100.0 & 100.0 & 0.09 & 0.33 & 0.15 & 1.00 \\
\hline
\end{tabular}

${ }^{1}$ Treatment: $\mathrm{MG}=$ maize grain as main source of energy in concentrate mixture, $\mathrm{HRG}=$ hybrid rye grain as a main source of energy in concentrate mixture, $\mathrm{OPRG}=$ open-pollinated rye grain as a main source of energy in concentrate mixture.

${ }^{2}$ Standard error of the mean.

${ }^{3}$ In reticulorumen, omasum and abomasum.

${ }^{4}$ Apparently digested.

${ }^{5}$ Neutral detergent fiber.

${ }^{6}$ Acid detergent fiber. 
Greater starch flow at the duodenum was observed for MG compared to HRG and OPRG ( $\mathrm{P}=0.01$; Table 4), and consequently, less starch was digested up to the duodenum and more in the intestine for MG compared to HRG and OPRG $(\mathrm{P}=0.01)$. However, the majority of starch consumed (79.5, 95.0, and 93.0\% for MG, HRG, and OPRG) was digested in the whole stomach, particularly for HRG and OPRG. Since total tract digestibility of starch was almost complete for all treatments, no differences for total tract digestibility of starch were observed between treatments. Apparent $\mathrm{CP}$ digestibility up to the duodenum was close to zero for MG treatment and negative for HRG and OPRG (-8.8 and $-12.6 \%$, respectively) but did not differ between treatments. On the other hand, $\mathrm{CP}$ digestibility in the intestine (calculated as $\%$ of flow to the intestine) tended to be greater for HRG and OPRG compared to MG $(\mathrm{P}=0.10)$. No other differences were observed between MG vs. HRG and OPRG. Moreover, no differences between HRG and OPRG for nutrient flow at the duodenum, digestibility in the stomach, intestine, and whole digestive tract were observed.

\section{Discussion}

In this study, we hypothesized that ruminal fermentation and nutrient digestibility of grain derived from hybrid and open-pollinated rye cultivars differ. To verify this hypothesis, wethers were fed not only diets with grain derived from hybrid or openpollinated rye cultivars, but also maize grain (derived from hybrid variety). Although substantial differences were observed between rye and maize grain feeding on the investigated parameters of ruminal fermentation and nutrient digestibility, no or only minor differences between hybrid rye or open-pollinated rye grain were detected. These results provide evidence for rejecting the hypothesis of this study.

Prior to an in-depth discussion of the results, the specificity and weaknesses of our experimental model need to be mentioned. Rye grain was compared with maize grain to better illustrate the differences between rapidly (rye) and slowly (maize) fermentable starch sources in the rumen and also potential differences between hybrid and open-pollinated rye grain. However, to limit the number of confounding factors between diets, only soybean meal was included in the diets (in addition to cereal grains) to equalize the CP content between treatments. Consequently, the experimental diets were similar for $\mathrm{CP}$ concentration but not starch concentration, the most important factor when it comes to the impacts of different cereal grains on ruminal fermentation. Specifically, the starch content was greater for MG compared to HRG and OPRG; thus, differences for ruminal $\mathrm{pH}$ between maize grain and rye grain use in the diet could be greater, whereas differences for starch digestibility up to the duodenum could be lower.

Nevertheless, the experimental model used in this study still allowed for illustrating overall differences between maize and rye grain in terms of ruminal fermentation and nutrient digestibility, and also not confounded by different starch concentration in the diet (and also NFC) comparison between hybrid and open-pollinated rye grains, which was the most important aim of this study. Particularly, starch intake 
did not differ between HRG and OPRG, although starch concentration was slightly higher for the latter one. Furthermore, one marker system was used in this study, which could have resulted in under- or overestimation of nutrient flow at the duodenum, with the former one being more probable (based on the substantial proportion of fiber digested in the intestine in the current study, as compared to the results of other studies; Titgemeyer, 1997). However, once again, the result of the current study allowed for a reasonable comparison of hybrid rye grain and open-pollinated rye grain usage in the diet on the investigated parameters of ruminal fermentation and nutrient digestion in sheep.

In general, maize starch has a slow rate and low extent of degradation in the rumen, whereas wheat, barley, and rye starche is rapidly and extensively degraded (Benninghoff et al., 2015; Krieg et al., 2017; Rajtar et al., 2020). These differences between maize and rye grain were also confirmed in the current study, as indicated by less starch digested in the whole stomach and more in the intestine, as well as a higher ruminal $\mathrm{pH}$ when the animals were fed $\mathrm{MG}$ compared to HRG and OPRG. As already mentioned, these differences could be even greater taking into account that starch intake was greater for MG compared to HRG and OPRG, indicating large difference between maize grain and rye grain in terms of their impact on ruminal fermentation and digestion in this region of the gastrointestinal tract. However, one has to take into account that in the current study, only several parameters of ruminal fermentation were investigated and that digestibility was measured in the whole stomach, with possible substantial contribution of not only rumen but also omasum to this digestibility (Ahvenjärvi et al., 2000). Although these differences between maize grain and rye grain are quite well known (Benninghoff et al., 2015; Krieg et al., 2017; Rajtar et al., 2020), a considerable variation may occur within starch sources, e.g., between batches of grain derived from the same species but different cultivars (Silveira et al., 2007; Zhao et al., 2016; Krieg et al., 2017). For example, in pigs, the digestibility of most amino acids in older rye cultivars was greater than that in newer cultivars of hybrid rye; however, few studies have evaluated the digestibility of hybrid rye in pigs to date (Strang et al., 2016). Also, using in vitro and in situ methods, Krieg et al. (2017) showed substantial differences in ruminal digestibility and degradability of rye grain derived from different genotypes. In contrast to the results of the aforementioned studies, in the current study, no differences between rye grain derived from various genotypes on ruminal fermentation and nutrient digestion were shown when used as a part of the sheep diets.

Non-starch polysaccharides are present in high concentrations in rye grain, with arabinoxylans, mixed-linked $\beta$-glucans, and cellulose being most abundant (Bach Knudsen, 1997). On a DM basis, the concentration of arabinoxylans in rye may vary greatly, ranging from 6 to 12\% (Hansen et al., 2003; Jürgens et al., 2012; Strang et al., 2016; Rodehutscord et al., 2016). Rye arabinoxylans are also more soluble in water and more fermentable than arabinoxylans present in other cereal grains (Le Gall et al., 2009; Jürgens et al., 2012). Moreover, the concentration of Klason lignin in rye may vary from 1 to $2 \%$ and that of ADL from 0.7 to $0.9 \%$ (Strang et al., 2016; Rodehutscord et al., 2016), of which increased concentrations reduce the digestibility of nutrients (Wenk, 2001). Although conducted on pigs, the results of a previous study 
indicate that the intake of particular carbohydrates present in rye (and cereal grains in general) may affect microbial fermentation in the gastrointestinal tract (Glitsø et al., 2000).

As such, taking into account possible differences in nutrient content and antinutritional factors between hybrid and open-pollinated rye grain (Strang et al., 2016; Makarska et al., 2007; Miedaner and Geiger, 2015), differences in investigated parameters of ruminal fermentation and nutrient digestion in different regions of the gastrointestinal tract were expected. A lack of such differences (except some minor differences for ruminal $\mathrm{pH}$ ) could simply be a result of no differences for concentrations of most carbohydrates between the hybrid rye grain and the open-pollinated rye grain used in the current study. Only a slightly greater starch concentration in open-pollinated rye compared to hybrid rye grain was observed (and also in the concentrate mixture fed to OPRG compared to HRG), which may explain the slightly lower ruminal $\mathrm{pH}$ for OPRG compared to HRG (Figure 1). However, the NFC concentration in the diet did not differ between OPRG and HRG as well as starch intake, indicating that the rye genotype affects ruminal fermentation to some extent.

It has been shown that the chemical composition of grain may be affected to a larger extent by environmental factors or cultivation (e.g., planting time, harvest time, fertilization) than by genotype (Andersson et al., 1993; Coles et al., 1997). For example, Boros et al. (unpublished) showed, unexpectedly, that hybrid rye grain contained more arabinoxylans and total dietary fiber than more traditional rye grain from open-pollinated cultivars. Consequently, ruminal fermentability of grain may be more significantly affected by environmental factors during vegetation than by the cultivar of the plant itself, as already discussed by others (Krieg et al., 2017). The chemical compositions of hybrid and open-pollinated rye grain used in the present study were similar, indicating that possible differences during cultivation and harvesting of rye used for this study did not have a substantial impact on the chemical composition of the grain or, alternatively, contributed to the similar composition. However, it has to be mentioned that in the current study, feed intake by the sheep was restricted and, in general, ruminal $\mathrm{pH}$ was quite high also for HRG and OPRG treatments. Thus, the experimental design of this study could allow for detecting only substantial - but not minor - differences between HRG and OPRG than could be observed in animals fed ad libitum.

Rumen $\mathrm{pH}$ is dependent on the rates of SCFA production and absorption, the secretion of salivary buffer, and the endogenous buffering capacity of feeds/digesta (Allen, 1997). Although reduced ruminal $\mathrm{pH}$ was observed when rye grain was fed to animals, there were, in general, no differences in total or individual concentrations of SCFA. The only difference noted was the greater valeric and isovaleric acid concentration in the rumen fluid when maize grain was fed to the animals. Those differences are undisputedly biased by the greater starch intake in the MG treatment compared to HRG and OPRG. However, valeric and isovaleric acid are a result of amino acid breakdown by microbes in the rumen and are required for the growth of ruminal microorganisms. In particular, valeric and isovaleric acid are used by microbes involved in fiber fermentation (Cline et al., 1958; Andries et al., 1987). Differences in the rate and extent of maize and rye fermentation in the rumen likely 
affected both feed protein breakdown and microbial protein synthesis in the rumen, also due to differences in starch concentration between diets, and thus, valerate and isovalerate synthesis and use, both contributing to the observed differences between the treatments (Cline et al., 1958; Muller, 1987). Of importance, both the molar proportion of valerate and isovalerate in total SCFA did not differ between HRG and OPRG, which provides further evidence of a lack of a substantial impact of rye grain derived from various genotypes on the investigated parameters of ruminal fermentation in the current study.

In the current study, crude protein flow at the duodenum exceeded CP intake, which resulted in negative digestibility coefficients for $\mathrm{CP}$ up to the duodenum. This was most likely due to the relatively low CP concentration in the diet $\approx 29.5 \%$ of $\mathrm{DM}$ ) in the current study; however, negative values for CP digestibility in forestomach can be observed also when the protein concentration in the diet is much higher (Chibisa et al., 2012). A low protein concentration in the diet enhances nitrogen recycling to the rumen, which, in combination with sufficient fermentable energy intake, allows for efficient microbial protein synthesis in the rumen (Titgemeyer, 1997). Thus, fermentable energy intake in the current study likely allowed for efficient microbial protein production in the rumen, irrespective of the grain source (rye or maize) that was used in the diet. The latter one is supported by no differences in the CP flow at the duodenum canal between treatments. However, the digestibility of $\mathrm{CP}$ in the intestine tended to be higher for rye grain compared to maize grain.

According to McAllister et al. (1993) and Krieg et al. (2017), interactions of the protein matrix with starch granules and variation in the properties of cereal grain proteins could contribute to the differences in starch degradation kinetics in the rumen. In our earlier studies, the kinetic of in situ CP degradation for rye grain and maize grain was similar to that of their starch degradation (Rajtar et al., 2020). Furthermore, in the mentioned study, the correlation between effective rumen degradation of starch and CP was high, supporting the results of other studies (Svihus et al., 2005; Krieg et al., 2017). In consequence, the rumen-undegradable fraction of protein derived from cereal grain was likely greater for MG than HRG and OPRG, although there were no differences for $\mathrm{CP}$ flow out of the rumen. Hence, the observed differences for $\mathrm{CP}$ digestion in the intestine can be attributed to differences in the composition of protein flowing into the duodenum. However, those differences were undisputedly also biased by the greater starch intake in the MG treatment. Furthermore, it cannot be excluded that increased starch flow to the intestine for the MG treatment could increase the amount of starch fermented in the intestine and associated microbial grow in the lower regions of the gastrointestinal tract (Li et al., 2012; Metzler-Zebeli et al., 2013). This could contribute to an underestimation of total tract digestibility of $\mathrm{CP}$ for the sheep fed a diet with maize grain.

\section{Conclusions}

Under the conditions of the current study, no differences in ruminal SCFA, ammonia, ruminal $\mathrm{pH}$, as well as nutrient digestion up to the duodenum and intestine were observed when sheep were fed diets with grain from hybrid or open-pollinated 
rye cultivars. Rye grain starch is more digestible up to the duodenum compared to starch of maize grain, which likely contributes to a lower rumen $\mathrm{pH}$ when rye grain is used in the diet compared to maize grain.

\section{Acknowledgements}

The authors would like to thank K. Strumiński, A. Marszałek, B. Dudzik and W. Malik for their technical support and K. Słota, O. Lasek, M. Sabatowicz, J. Flaga and Ł. Korytkowski for assistance with sample collection. Also, the consultations with E. Wierzchoś in terms of veterinary care of the animals and support of M. Gzowska with feed samples analysis are acknowledged.

\section{References}

AACC (2011). International approved methods of analysis. 11th Ed. St. Paul, MN, USA.

Ahvenjärvi S., Vanhatalo A., Huhtanen P., Varvikko T. (2000). Determination of reticulo-rumen and whole-stomach digestion in lactating cows by omasal canal or duodenal sampling. Brit. J. Nutr., 83: 67-77.

A 11 e $\mathrm{n}$ M.S. (1997). Relationship between fermentation acid production in the rumen and the requirement for physically effective fiber. J. Dairy Sci., 80: 1447-1462.

A n d e r s s o n R., We ster 1 d E., Tilly A.C., Åman P. (1993). Natural variations in the chemical composition of white flour. J. Ceral. Sci., 17: 183-189.

Andries J.I., B uysse F.X., D e Brabander D.L., Cottyn B.G. (1987). Isoacids in ruminant nutrition: Their role in ruminal and intermediary metabolism and possible influences on performances - A review. Anim. Feed Sci. Technol., 18: 169-180.

Arczewska-Włosek A., Świątkiewicz S., Bederska- Łojewska D., Orczewska- Dudek S., S zczurek W., B oros D., Fraś A., Tomaszewska E., Dobrowolski P., Muszyński S., Kwiecień M., S chwarz T. (2019). The efficiency of xylanase in broiler chickens fed with increasing dietary levels of rye. Animals, 9: 46.

B a ch Knudsen K.E. (1997). Carbohydrate and lignin contents of plant materials used in animal feeding. Anim. Feed Sci. Technol., 67: 319-338.

Bederska-Łojewska D., A rczewska-Włosek A., Świątkiewicz S., Orczewska- Dudek S., S chwarz T., Puchała M., Krawczyk J., B oros D., Fraś A., Micek P., R a j t a r P. (2019). The effect of different dietary levels of hybrid rye and xylanase addition on the performance and egg quality in laying hens. Brit. Poultry Sci., 60: 423-430.

B enningh off J., P a s chke-B e es e M., S üd e kum K.H. (2015). In situ and in vitro ruminal degradation of maize grain and untreated or xylose-treated wheat, barley and rye grains. Anim. Feed Sci. Tech., 210: 86-93.

Chibis a G.E., Christen se n D.A., Muts vangwa T. (2012). Effects of replacing canola meal as the major protein source with wheat dried distillers grains with solubles on ruminal function, microbial protein synthesis, omasal flow, and milk production in cows. J. Dairy Sci., 95: 824-841.

Cline J.H., Hershberger T.V., B entley O.G. (1958). Utilization and/or synthesis of valeric acid during the digestion of glucose, starch and cellulose by rumen micro-organisms in vitro. J. Anim. Sci., 17: 284-292.

Coles G.D., Hartunian-Sowa S.M., Jamieson P.D., Hay A.J., A twell W.A., Fulc h e r R.G. (1997). Environmentally-induced variation in starch and non-starch polysaccharide content in wheat. J. Cereal Sci., 26: 47-54.

C on w a y E.J. (1962). Ammonia. General method. In: Microdiffusion analysis and volumetric error. Crosby Lockwood and Son Ltd., London, UK, pp. 98-100.

En g l y s t H.N., C u m m in g s J.H. (1984). Simplified method for the measurement of total non-starch polysaccharides by gas-liquid chromatography of constituent sugars as alditol acetates. Analyst, 109: 937-942. 
E rw in E.S., M a r c o G.J., E m e r y E.M. (1961). Volatile fatty acid analyses of blood and rumen fluid by gas chromatography. J. Dairy Sci., 44: 1768-1771.

Faisant N., Planchot V., Kozlowski F., Pacourent M.P., Colonna P., Champ M. (1995). Resistant starch determination adapted to products containing high level of resistant starch. Sci. Alim., 15: 83-89.

G e i g e r H.H., M i e d a n e r T. (2009). Rye breeding. In: Cereals (Handbook of plant breeding), 1st ed., Carena M.J. (ed.). Springer: New York, NY, USA, pp. 157-181.

G lit s ø L.V., J e n s en B.B., B a ch Knuds e n K.E. (2000). In vitro fermentation of rye carbohydrates including arabinoxylans of different structure. J. Sci. Food Agr., 80: 1211-1218.

Górka P., Śliw iński B., Flaga J., Wi eczorek J., Godlewski M.M., Wierzchoś E., Z a bi e ls k i R., Kow a ls k i Z.M. (2017). Effect of butyrate infusion into the rumen on butyrate flow to the duodenum, selected gene expression in the duodenum epithelium, and nutrient digestion in sheep. J. Dairy Sci., 95: 2144-2155.

Hans en H.B., Ras mus s en C.V., B a ch Knudsen K.E., Hans en $\AA$. (2003). Effects of genotype and harvest year on content and composition of dietary fibre in rye (Secale cereale L.) grain. J. Sci. Food Agric., 83: 76-85.

Heuzé V., Tran G., Nozi ère P., Less ire M., L e b a s F. (2015). Rye grain and by-products. Feedipedia, a programme by INRA, CIRAD, AFZ and FAO. https://www.feedipedia.org/node/225. Last updated on October 26, 2015, 15:37.

INRA (Institut National de la Recherche Agronomique) (2007). Feeding of cattle, sheep and goats. Requirements for animals. Food values (in French: Alimentation des bovins, ovins et caprins. Besoins des animaux. Valeurs des aliments). Éditions Quæ (INRA), Versailles, France.

Jür g e n s H.-U., J a n s e n G., W e g e n e r C.B. (2012). Characterisation of several rye cultivars with respect to arabinoxylans and extract viscosity. J. Agric. Sci., 4: 1-12.

Katin a K., Hartika in en K., P o u t a n e n K. (2014). Process-induced changes in rye foods - rye baking. In: Rye and Health, K. Poutanen, P. Åman (eds). AACC International Press, pp. 7-21.

Krieg J., S i e g fried N., S te ingas s H., R od e hu t s c ord M. (2017). In situ and in vitro ruminal starch degradation of grains from different rye, triticale and barley genotypes. Animal, 11: 1745-1753.

Le Gall M., Serena A., Jørgensen H., Theil P.K., B a ch Knudsen K.E. (2009). The role of whole-wheat grain and wheat and rye ingredients on the digestion and fermentation processes in the gut - a model experiment with pigs. Brit. J. Nutr., 102: 1590-1600.

Li S., Khafipour E., Krause D.O., Kroeker A., Rodriguez-Lecompte J.C., Gozh o G.N., P l a i zi e r J.C. (2012). Effects of subacute ruminal acidosis challenges on fermentation and endotoxins in the rumen and hindgut of dairy cows. J. Dairy Sci., 95: 294-303.

L o y D.D., L und y E.E. (2019). Nutritional properties and feeding value of corn and its coproducts. https://doi.org/10.1016/B978-0-12-811971-6.00023-1

Makarska E., Gruszecka D., Gardzielewska A. (2007). The content of alkylresorcinols and trypsin inhibitors activity in translocational rye strains and parental components $\mathrm{Se}$ cale cereale L. and Dasypyrum villosum (L.) P. Candargy. Ann. UMCS, Lublin, Polonia, LXII: $117-121$.

Mc All is ter T.A., Phillippe C., R o de L.M., Cheng K.J. (1993). Effect of the protein matrix on the digestion of cereal grains by ruminal microorganisms. J. Anim. Sci., 71: 205-212.

McGrath J., Duval S.M., Tamass i L.F.M, Kindermann M., Stemmler R.T., de Gouve V.N., A c e do T.S., I m mig I., Willi a m s S.N., C eli a P. (2018). Nutritional strategies in ruminants: A lifetime approach. Res. Vet. Sci., 116: 28-39.

Metzler-Zebeli B.U., Hollmann M., S abitzer S., Podstatzky-Lichtenstein L., $\mathrm{K} 1$ e in D., Z e b e li Q. (2013). Epithelial response to high-grain diets involves alteration in nutrient transporters and $\mathrm{Na}+/ \mathrm{K}+-\mathrm{ATPase}$ mRNA expression in rumen and colon of goats. J. Anim. Sci., 91: $4256-4266$.

M i e d a n e r T., G e i g e r H.H. (2015). Biology, genetics, and management of ergot (Claviceps spp.) in rye, sorghum, and pearl millet. Toxins, 7: 659-678.

Mulle r L.D. (1987). Branched chain fatty acids (isoacids) and valeric acid for ruminants. Prof. Anim. Sci., 3: 9-12.

P e nner G.B., B e a u che min K.A., Muts vang wa T. (2006). An evaluation of the accuracy and 
precision of a stand-alone submersible continuous ruminal pH measurement system. J. Dairy Sci., 89: 2132-2140.

Penner G.B., A s chenbach J.R., Gabel G., Oba M. (2009). Technical note: Evaluation of a continuous ruminal $\mathrm{pH}$ measurement system for use in noncannulated small ruminants. J. Anim. Sci., 87: 2363-2366.

P f is t e r J.A. (1985). Technical notes: An effective fecal harness for free-grazing goats. J. Range Manage., 38: 184-185.

Pieszka M., Kamyczek M., Rudzki B., Łopuszańska-Rusek M., Pieszka M. (2015). Evaluation of the usefulness of hybrid rye in feeding Polish Holstein-Friesian dairy cows in early lactation. Ann. Anim. Sci., 15: 929-943.

R a j t a r P., Górk a P., S c hwar z T., M i c e k P. (2020). Effect of hybrid rye and maize grain processing on ruminal and postruminal digestibility parameters. Ann. Anim. Sci., 20: 1065-1083.

Roberts on J.B., Van S o e st P.J. (1981). The detergent system analysis and its application to human foods. In: The analysis of dietary fiber in food, J. Theander (ed.). Dekker INC, pp. 123-157.

Rodehutscord M., Rückert C., Maurer H.P., Schenkel H., Schipprack W., B a ch Knudsen K.E., S cholle n berger M., La ux M., Eklund M., S i e g e rt W. (2016). Variation in chemical composition and physical characteristics of cereal grains from different genotypes. Arch. Anim. Nutr., 70: 87-107.

Schwarz T., Kuleta W., Turek A., Tuz R., Nowicki J., Rudzki B., Bartlewski P.M. (2015). Assessing the efficiency of using a modern hybrid rye cultivar for pig fattening, with emphasis on production costs and carcass quality. Anim. Prod. Sci., 55: 467-473.

Seifried N., Steingas s H., H offmann N., R od e hut s c ord M. (2016). In situ starch and crude protein degradation in the rumen and in vitro gas production kinetics of wheat genotypes. J. Anim. Physiol. Anim. Nutr., 101: 779-790.

S h a r m a H.R., In g a $11 \mathrm{~s}$ J.R., M c K i r d y J.A., S a n for d L.M. (1981). Evaluation of rye grain in the diets of young Holstein calves and lactating dairy cows. J. Dairy Sci., 64: 441-448.

S i d d on s R.C., P a ra din e J., B e ever D.E., C ornell P.R. (1985). Ytterbium acetate as a particulate-phase digesta-flow marker. Brit. J. Nutr., 54: 509-519.

S i l ve i r a C., O b a M., Yang W.Z., B e a u c h e m in K.A. (2007). Selection of barley grain affects ruminal fermentation, starch digestibility, and productivity of lactating dairy cows. J. Dairy Sci., 90 : 2860-2869.

S m i t M.N., Z h o u X., L a n d e r o J.L., Young M.G., B e 1 tr a n e n a E. (2019). Increasing hybrid rye level substituting wheat grain with or without enzyme on growth performance and carcass traits of growing-finishing barrows and gilts. Tran. Anim. Sci., 3: 1561-1574.

S trang E.J.P., Ek l und M., R o s e n f e l d e r P., S a u e r N., H t o o J.K., M o s e n th in R. (2016). Chemical composition and standardized ileal amino acid digestibility of eight genotypes of rye fed to growing pigs. J. Anim. Sci., 94: 3805-3816.

S vihus B., Uhlen A.K., Harstad O.M. (2005). Effect of starch granule structure, associated components and processing on nutritive value of cereal starch: A review. Anim. Feed Sci. Tech., 122: 303-320.

The ander O., Åman P., We sterlund E., Anders s on R., P e t ters s on D. (1995). Total dietary fiber determined as neutral sugar residues, uronic acids and klason lignin, gas chromatographic-colorimetric-gravimetric method (Uppsala Method), AOAC method 994.13. Official Methods of Analysis, 16th ed., 1st suppl.

T i t g e m e y e r E.C. (1997). Design and interpretation of nutrient digestion studies. J. Anim. Sci., 75: 2235-2247.

van Rys sen J.B.J., Mavimbela D.T. (1999). Broiler litter as a source of selenium for sheep. Anim. Feed Sci. Technol., 78: 263-272.

Warren F.S., Langille J.E., Riordan H.A. (1963). Rye for forage and grain in the Atlantic Provinces. Can. Dep. Agric. Publ., 1185.

We n k C. (2001). The role of dietary fibre in the digestive physiology of the pig. Anim. Feed Sci. Technol., 90: 21-33.

W ęs i erska E., Ni e m c zyńs ka K., Pasternak M., Arczews ka - W łos ek A. (2019). Selected physical and chemical characteristics of eggs laid by hens fed diets with different levels of hybrid rye. Ann. Anim. Sci., 19: 1009-1020. 
Zh a o Y., Yan S., He Z., A ne le U.Y., S w ift M.L., M c A 11 is t e r T.A., Yang W. (2016). Effect of starch content and processing method on in situ ruminal and in vitro intestinal digestion of barley grain in beef heifers. Anim. Feed Sci. Tech., 216: 121-128.

Received: 10 VII 2020

Accepted: 19 XI 2020 